Keywords: Tank Closure Grout

High Level Waste Tank

Retention: Permanent

\title{
Tank 18-F and 19-F \\ Tank Fill Grout Scale Up Test Summary
}

David B. Stefanko

Christine A. Langton

December 2011

Savannah River National Laboratory Savannah River Nuclear Solutions, LLC Aiken, SC 29808

Prepared for the U.S. Department of Energy under contract number DE-AC09-08SR22470.

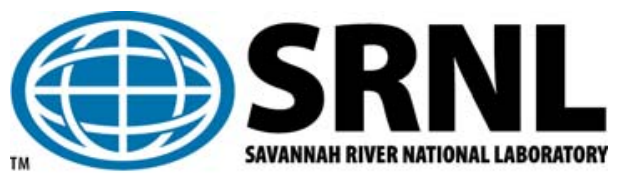


SRNL-STI-2011-00749

Revision 0

\section{DISCLAIMER}

This work was prepared under an agreement with and funded by the U.S. Government. Neither the U.S. Government or its employees, nor any of its contractors, subcontractors or their employees, makes any express or implied:

1. warranty or assumes any legal liability for the accuracy, completeness, or for the use or results of such use of any information, product, or process disclosed; or

2. representation that such use or results of such use would not infringe privately owned rights; or

3. endorsement or recommendation of any specifically identified commercial product, process, or service.

Any views and opinions of authors expressed in this work do not necessarily state or reflect those of the United States Government, or its contractors, or subcontractors.

\section{Printed in the United States of America}

Prepared for U.S. Department of Energy 


\section{REVIEWS AND APPROVALS}

AUTHORS:

D. B. Stefanko, E\&CPT Research Programs

Date

C. A. Langton, E\&CPT Research Programs

Date

TECHNICAL REVIEW:

M. G. Serrato, E\&CPT Research Programs / SRNL

Date

APPROVAL:

F. M. Pennebaker, E\&CPT Research Programs, Manager

Date

S. L. Marra, E\&CPT Research Programs, Manager

Date

P. E. Carroll, FY12 Closure Project Engineering, SRR, Manager

Date

J. E. Herbert, Waste Removal and Tank Closure, SRR Project Operations, Manager Date 


\section{ACKNOWLEDGEMENTS}

URS Washington Group, Quality and Testing Division management and technical personnel provided use of the SRS Civil Engineering Laboratory test equipment, support and input that was essential for performing the tests and obtaining the results in this report. W. Pope, Jr., W. B. Mhyre, and J. T. Waymer, URS, are recognized as key contributors.

SRR Project Engineering, SRR Project Operations and SRR Construction provided the semi adiabatic mock up form, testing location and test plan. They also provided much appreciated project review, funding and support for this effort.

Bob Fogle, SRNL R\&D Engineering, provided the thermocouples and assistance with calibration before the sensors were installed in the semi-adiabatic test form. 


\section{EXECUTIVE SUMMARY}

High-level waste (HLW) tanks 18-F and 19-F have been isolated from FTF facilities [1]. To complete operational closure the tanks will be filled with grout for the purpose of: 1) physically stabilizing the tanks, 2) limiting / eliminating vertical pathways to residual waste, 3) entombing waste removal equipment, 4) discouraging future intrusion, and 5) providing an alkaline, chemical reducing environment within the closure boundary to control speciation and solubility of select radionuclides.

This report documents the results of a four cubic yard bulk fill scale up test on the grout formulation recommended for filling Tanks $18-\mathrm{F}$ and 19-F. Details of the scale up test are provided in a Test Plan [2]. The work was authorized under a Technical Task Request (TTR), HLE-TTR-2011-008 [3], and was performed according to Task Technical and Quality Assurance Plan (TTQAP), SRNL-RP-201100587 [4].

The bulk fill scale up test described in this report was intended to demonstrate proportioning, mixing, and transportation of material produced in a full scale ready mix concrete batch plant. In addition, the material produced for the scale up test was characterized with respect to fresh properties, thermal properties, and compressive strength as a function of curing time.

A grout formulation for filling Tanks 18-F and 19-F was developed by SRNL during $2011[5,6]$. The recommended material is a flowable zero bleed structural fill containing $3 / 8$ inch gravel. The ingredients and proportions in the mix are listed in the table. Properties of this grout are provided elsewhere [6].

\begin{tabular}{|c|c|c|c|c|c|c|c|c|c|}
\hline $\begin{array}{c}\text { Mix } \\
\text { Number }\end{array}$ & $\begin{array}{c}\text { Cement } \\
\text { Type } \\
\text { I/II }\end{array}$ & $\begin{array}{c}\text { Slag } \\
\text { Grade } \\
100\end{array}$ & \begin{tabular}{|c} 
Fly \\
Ash \\
Class \\
F \\
\end{tabular} & \begin{tabular}{|c} 
Type G \\
Shrinkage \\
Compensating \\
Component
\end{tabular} & \begin{tabular}{|c} 
Sand \\
Quartz
\end{tabular} & \begin{tabular}{|c} 
Gravel \\
No. 8 \\
$3 / 8$ in.
\end{tabular} & Water & $\begin{array}{c}\text { HRWR } \\
\text { SIKA Visco } \\
\text { Crete } 2100\end{array}$ & $\begin{array}{c}\text { VMA } \\
\text { Diutan Gum } \\
\text { Kelco-Crete } \\
\text { DG }\end{array}$ \\
\hline & \multicolumn{6}{|c|}{ Lbs / cyd } & Gal / cyd & Fl oz / cyd & $\mathrm{g} / \mathrm{cyd}$ \\
\hline LP\#8-16 & 125 & 210 & 363 & 0 & 1790 & 800 & 48.5 & 41 & 200 \\
\hline
\end{tabular}

Four cubic yards of grout were batched at the LaFarge North America ${ }^{a}$ batch plant in Jackson SC. LaFarge substituted two W. R. Grace products for the admixtures used in the recommended tank fill. The alternative admixtures were approved by SRNL and were used in some of the SRNS reactor in-situ decommissioning grouts. The order of addition of these admixtures was to 1) add W. R. Grace ADVA 575 , high range water reducer (HRWR), at the central mixing station and 2) add a stabilized mixture of ADVA 575 and Diutan Gum to the truck at the test station. The amount of the stabilized mixture was determined based on the ASTM C1611 slump flow results at the test station.

Cement contacted the water in the transit mixer at $0724 \mathrm{hr}$. The material was approved at the batch plant at $0745 \mathrm{hr}$ based on slump flow. The delivery truck arrived at the Site at $0800 \mathrm{hr}$. At $0815 \mathrm{hr}$, the first sample was collected from the truck at the F-Tank Farm test site.

Several property measurements were identified in the bulk fill grout scale up test plan. Some of the properties were measured at both the batch plant and at the point of delivery in F-Area. The slump flow per ASTM C1611 was 25.5 inches for material measured in F-Area which is 2.5 inch less than the slump flow measured at the batch plant. The value measured in F-Area was within the acceptable range

${ }^{a}$ LaFarge was recently acquired by ARGOS Ready Mix, LLC. 
in the tank fill procurement specification (24 to 28 inches) and corresponded to values measured in the laboratory [6].

The static gel time was significantly shorter than the time measured for a sample prepared in the laboratory, 9.5 inches at 30 minutes (laboratory sample) compared to 0 inches at 30 minutes (production sample). Different mixing conditions, a longer time between batching and testing, and ambient conditions may have contributed to part of this difference. However, it is more likely that ADVA 575 was not completely equivalent to the SIKA ViscoCrete 2100 and had slightly less gel retardation effect. Concrete admixtures are complex blends of several active chemicals and need to be adjusted to obtain desirable results. In this case a small amount of admixture to extend the static working time or adjustment of the ADVA 575 and EXP 958 (mixture of ADVA 575 and Diutan Gum) is warranted. Such adjustments may be required often during full-scale production.

There was no significant change in the air content, unit weight and temperature of the grout for values measured at the concrete batch plant versus values measured at F-Tank Farm. Air content in the grout increased 0.3 volume percent after leaving the LaFarge batch plant. This reduced the measured unit weight from 136.6 to $135.1 \mathrm{lb} / \mathrm{cft}$. The increase in the ambient temperature and grout temperature was $<3^{\circ} \mathrm{F}$

The set time of the scale up mix was 7.5 hours. Set time was determined using the Ultrasonic Pulse Velocity (UPV) method. A small decrease in signal velocity was noticed just before the grout set. The cause for the slight velocity decrease is unknown and attributed to someone checking the sample during the test. The measured set time was less than the 24 hour requirement to sustain next day operations and meets the production requirement for filling the waste tanks.

The scale up testing confirmed that offsite batching at a commercial plant and delivering the bulk fill material for filling Tanks $18-\mathrm{F}$ and $19-\mathrm{F}$ is feasible. Material batching and delivery to the F area Tank Farm was achieved in less than one hour.

The average compressive strength measured from samples cured 28 days was 2800 psi. This meets the Performance Assessment (PA) and Engineering requirement ( $>2000$ psi at 28 day).

A one cubic yard insulated plywood form with an insulated lid was poured with the tank fill grout for measuring the semi-adiabatic temperature rise. Thermocouples were installed at the center of the box at several elevations. Additional thermocouples were placed along the center of one side and in a corner of the box. Temperature readings were collected for approximately one month. The peak temperature occurred after 82 hours. The semi-adiabatic temperature rise was $23^{\circ} \mathrm{C}$. This meets the objective for a grout that can be mass placed.

Saturated hydraulic conductivity, density and porosity were identified as optional parameters in the scale up test plan and were not measured. 


\section{TABLE OF CONTENTS}

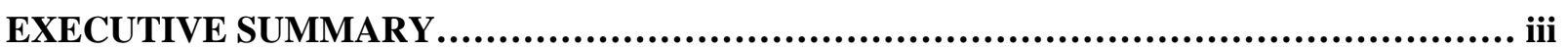

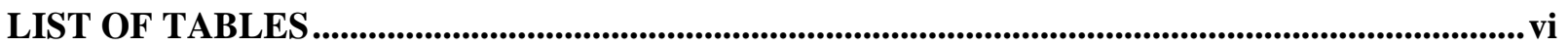

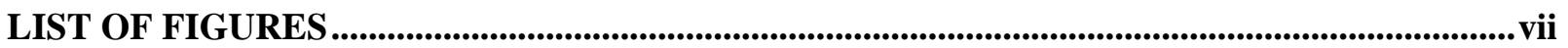

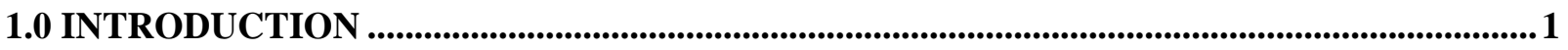

1.1 Objective ................................................................................................................................................ 1

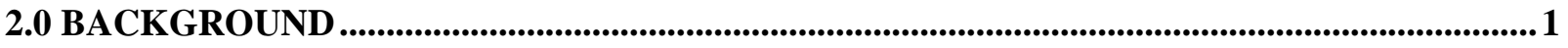

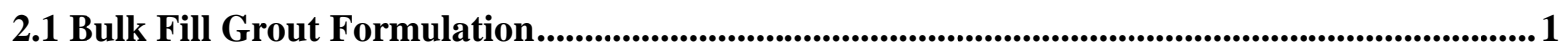

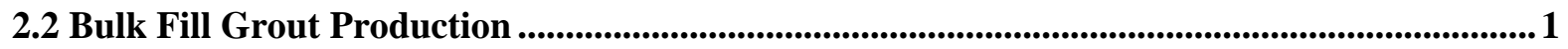

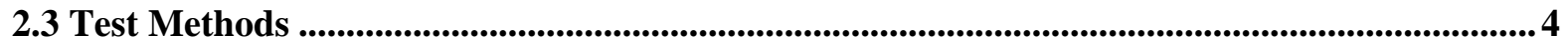

2.4 Description of Semi Adiabatic Form ..................................................................................................... 4

2.5 Semi Adiabatic Form Filling ..........................................................................................................................5

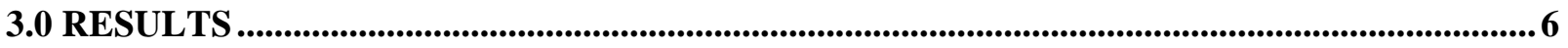

3.1 Fresh Properties ..................................................................................................................................... 6

3.2 Thermal Properties ......................................................................................................................................... 8

3.3 Cured Properties ...........................................................................................................................................9

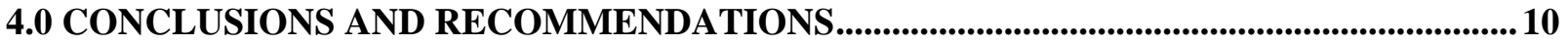

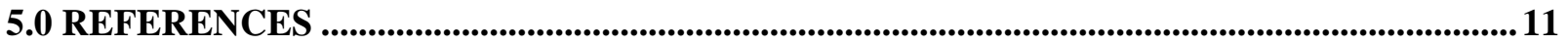




\section{LIST OF TABLES}

Table 2-1. Tanks 18 and 19-F Bulk Fill Material Recommendation [6]............................................. 1

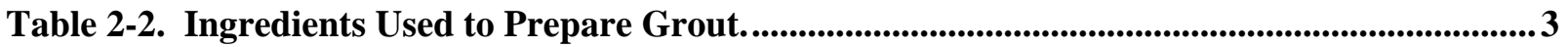

Table 2-3. Size Distribution of the Sand and No. 8 Stone [Waymer, 2011]....................................3

Table 2-4. Test Methods Used to Determine Grout Properties. ........................................................4

Table 3-1. Fresh Properties of the Bulk Fill Scale Up Mix....................................................................... 7

Table 3-2. Cured Properties of the Bulk Fill Scale Up Mix........................................................10 


\section{LIST OF FIGURES}

Figure 2-1. Batch ticket for grout ordered for the scale up test. ....................................................2

Figure 2-2. Admixture dose adjustment at the LaFarge batch plant based on ASTM C1611

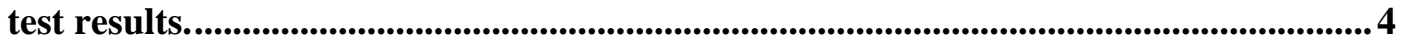

Figure 2-3. (a) Semi adiabatic test form and (b) Data logger set up. ................................................ 5

Figure 2-4. (a) Bulk tank fill grout placed into the semi adiabatic form and (b) Near full form....5

Figure 3-1. Spread under static conditions, (a) initial, (b) Top left 15 minutes, Top right 30 minutes. ..................................................................................................................................... 6

Figure 3-2. Velocity variation with time through a sample of the bulk fill grout collected from the scale up test batch. ................................................................................................................

Figure 3-3. Tank fill grout - Semi-adiabatic temperature results for the one cubic yard monolith prepared on 8-31-2011 ..................................................................................8

Figure 3-4. Map of thermocouple sensor locations for one cubic yard monolith................................9 


\section{LIST OF ABBREVIATIONS}

\begin{tabular}{ll} 
ASTM & American Society of Testing and Materials \\
FTF & F-Area Tank Farm \\
HLW & High Level Waste \\
NM & Not measured \\
PA & Performance Assessment \\
QC & Quality Control \\
SEFA & South Eastern Fly Ash \\
SRNL & Savannah River National Laboratory \\
SRNS & Savannah River Nuclear Solutions, LLC \\
SRR & Savannah River Remediation, LLC \\
SRS & Savannah River Site \\
TTQAP & Task Technical and Task Quality Assurance Plan \\
TTR & Technical Task Request \\
UPV & Ultrasonic Pulse Velocity \\
cu ft & cubic ft \\
cyd & cubic yard \\
$\mathrm{ft}$ & foot or feet \\
hr & hour \\
lb & pound \\
min. & minute \\
vol.\% & pounds per square inch (gauge) \\
& volume percent \\
\hline
\end{tabular}




\subsection{INTRODUCTION}

High-level waste (HLW) tanks 18-F and 19-F have been isolated from FTF facilities [1]. To complete operational closure the tanks will be filled with grout for the purpose of: 1) physically stabilizing the tanks, 2) limiting / eliminating vertical pathways to residual waste, 3) entombing waste removal equipment, 4) discouraging future intrusion, and 5) providing an alkaline, chemical reducing environment within the closure boundary to control speciation and solubility of select radionuclides.

This report documents the results of a four cubic yard bulk fill scale up test on the grout formulation recommended for filling Tanks 18-F and 19-F. Details of the scale up test are provided in a Test Plan [2]. The work was authorized under a Technical Task Request (TTR), HLE-TTR-2011-008 [3], and was performed according to Task Technical and Quality Assurance Plan (TTQAP), SRNL-RP-201100587 [4].

\subsection{Objective}

The bulk fill scale up test described in this report was intended to demonstrate proportioning, mixing, and transportation, of material produced in a full scale ready mix concrete batch plant. In addition, the material produced for the scale up test was characterized with respect to fresh properties, thermal properties, and compressive strength as a function of curing time.

\subsection{BACKGROUND}

\subsection{Bulk Fill Grout Formulation}

A grout formulation for filling Tanks 18-F and 19-F was developed by SRNL during $2011[5,6]$. The recommended material is a flowable zero bleed structural fill containing $3 / 8$ inch gravel. The ingredients and proportions in the mix are listed in Table 2-1. Properties of this grout are provided elsewhere [6].

Table 2-1. Tanks 18 and 19-F Bulk Fill Material Recommendation [6].

\begin{tabular}{|c|c|c|c|c|c|c|c|c|c|}
\hline $\begin{array}{c}\text { Mix } \\
\text { Number }\end{array}$ & $\begin{array}{c}\text { Cement } \\
\text { Type } \\
\text { I/II }\end{array}$ & $\begin{array}{c}\text { Slag } \\
\text { Grade } \\
100\end{array}$ & \begin{tabular}{|c} 
Fly \\
Ash \\
Class \\
F
\end{tabular} & \begin{tabular}{|c} 
Type G \\
Shrinkage \\
Compensating \\
Component
\end{tabular} & \begin{tabular}{|c} 
Sand \\
Quartz
\end{tabular} & $\begin{array}{c}\text { Gravel } \\
\text { No. } 8 \\
3 / 8 \text { in. }\end{array}$ & Water & \begin{tabular}{|c} 
HRWR \\
SIKA Visco \\
Crete 2100
\end{tabular} & $\begin{array}{c}\text { VMA } \\
\text { Diutan Gum } \\
\text { Kelco-Crete } \\
\text { DG }\end{array}$ \\
\hline & \multicolumn{6}{|c|}{ Lbs / cyd } & Gal / cyd & Fl oz / cyd & g/cyd \\
\hline LP\#8-16 & 125 & 210 & 363 & 0 & 1790 & 800 & 48.5 & 41 & 200 \\
\hline
\end{tabular}

\subsection{Bulk Fill Grout Production}

Four cubic yards of grout were batched at the LaFarge North America ${ }^{2}$ batch plant in Jackson SC. The batch ticket for the material ordered for the scale up test is provided in Figure 2-1. Material suppliers for the grout ingredients are listed in Table 2-2. LaFarge substituted two W. R. Grace products for the admixtures used in the tank fill mix development testing. The alternative admixtures were approved by

\footnotetext{
${ }^{2}$ LaFarge was recently acquired by ARGOS Ready Mix, LLC.
} 
SRNL and were used in some of the SRNS reactor in-situ decommissioning grouts. The order of addition of these admixtures was to 1) add W. R. Grace ADVA 575, high range water reducer (HRWR), at the central mixing station and 2) add a stabilized mixture of ADVA 575 and Diutan Gum to the truck at the test station. The amount of the stabilized mixture was determined based on the ASTM C1611 slump flow results at the test station. See Figure 2-2.

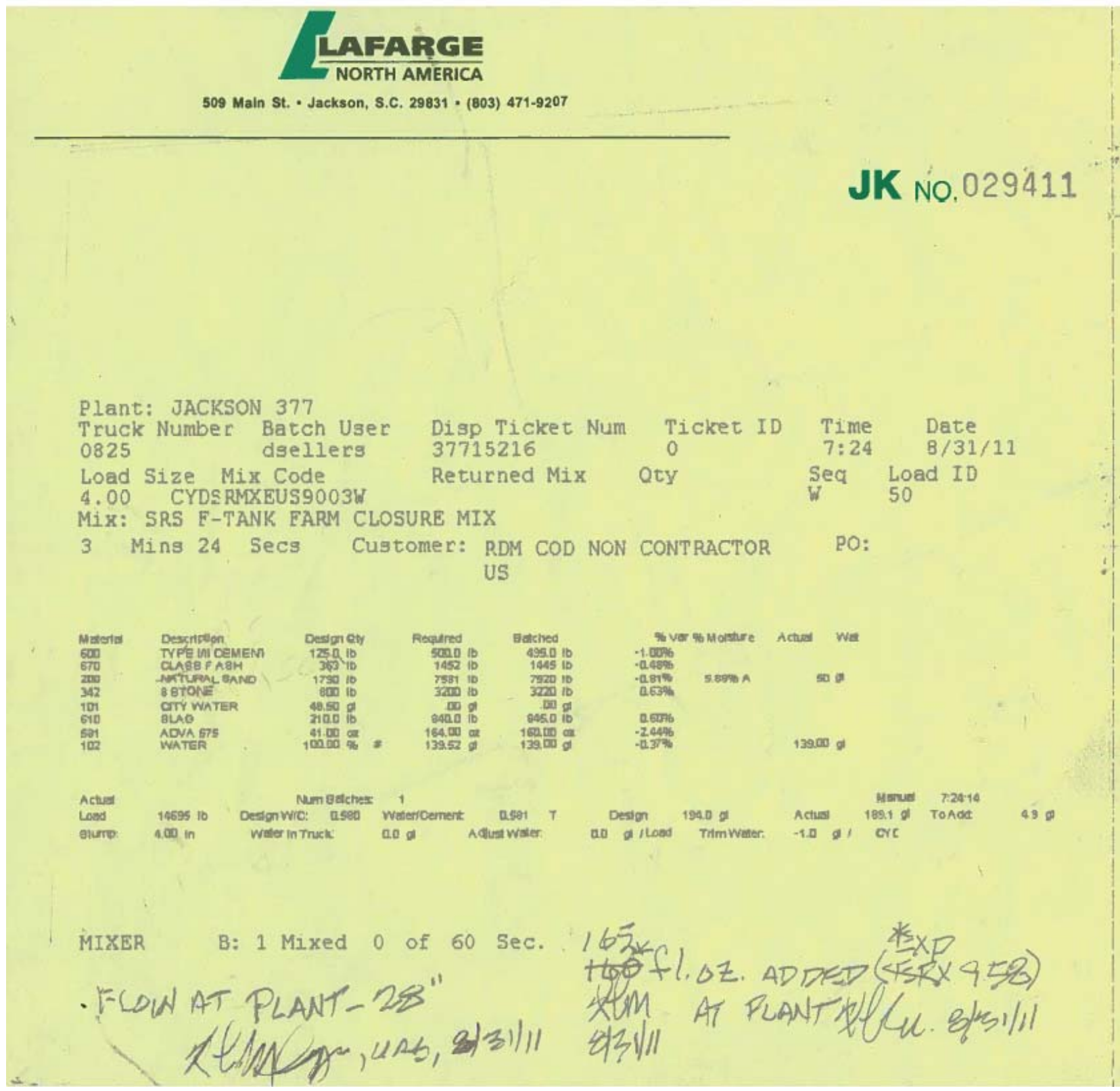

Figure 2-1. Batch ticket for grout ordered for the scale up test.

Cement contacted the water in the transit mixer at $0724 \mathrm{hr}$. The material was approved at the batch plant at $0745 \mathrm{hr}$ based on slump flow of $30 \times 26$ inches, (surface supporting test board was slightly irregular). The delivery truck arrived at the Site at $0800 \mathrm{hr}$. At $0815 \mathrm{hr}$, the first sample was collected from the truck at the F-Tank Farm test site. 
Table 2-2. Ingredients Used to Prepare Grout.

\begin{tabular}{|l|l|l|}
\hline \multicolumn{1}{|c|}{ Material } & Specification & \multicolumn{1}{c|}{ Supplier / Address } \\
\hline $\begin{array}{l}\text { Portland cement } \\
\text { (Type I/II) }\end{array}$ & ASTM C150 & $\begin{array}{l}\text { LaFarge,Cement } \\
\text { Harleyville, SC obtained from Lafarge Ready } \\
\text { Mix Augusta, GA }\end{array}$ \\
\hline $\begin{array}{l}\text { Slag cement } \\
\text { (Grade 100) }\end{array}$ & ASTM C989 & $\begin{array}{l}\text { Holcim, Inc., 3235 Satellite Blvd. } \\
\text { Duluth, GA 30096 }\end{array}$ \\
\hline $\begin{array}{l}\text { Fly ash } \\
\text { (Class F) }\end{array}$ & ASTM C618 & $\begin{array}{l}\text { Wateree Power Plant, SC } \\
\text { SEFA, Inc. }\end{array}$ \\
\hline Concrete sand & ASTM C33 & $\begin{array}{l}\text { SCMI, Clearwater SC } \\
\text { obtained from LaFarge Ready Mix, Jackson, SC }\end{array}$ \\
\hline $\begin{array}{l}\text { No. 8 stone } \\
\text { 3/8 inch gravel (granite) }\end{array}$ & ASTM C33 & $\begin{array}{l}\text { Martin Marietta Quarry Augusta, GA } \\
\text { obtained from LaFarge Ready Mix, Jackson, SC }\end{array}$ \\
\hline HRWR & & \\
\hline ADVA 575* & ASTM C494 Type F & W. R. Grace Corporation \\
\hline Viscosifier & & W. R. Grace Corporation \\
\hline EXP 958** (Diutan Gum) & & $\begin{array}{l}\text { Jackson, SC } \\
\text { Municipal Water Supply }\end{array}$ \\
\hline Potable water & &
\end{tabular}

* Sika ViscoCrete 2100 was used in the laboratory testing.

** EXP 958 is a stabilized mixture of ADVA 575 and Kelco-Crete Diutan ${ }^{\circledR}$ provided by CP Kelco, Inc., 8355 Aero Dr., San Diego, CA 92123.

Table 2-3. Size Distribution of the Sand and No. 8 Stone [Waymer, 2011].

\begin{tabular}{|c|c|c|c|c|}
\hline Property & \multicolumn{2}{|c|}{ Concrete Sand } & \multicolumn{2}{|c|}{ No. 8 Aggregate (3/8 inch) } \\
\hline Bulk Unit Weight $\left(\mathrm{lb} / \mathrm{ft}^{3}\right)$ & \multicolumn{2}{|c|}{$85 @ 1.6$ wt. \% SSD* } & \multicolumn{2}{|c|}{$93 @ 0.6$ wt. \% SSD* } \\
\hline Specific Gravity (particle) & \multicolumn{2}{|c|}{2.65} & \multicolumn{2}{|c|}{2.65} \\
\hline Composition & \multicolumn{2}{|c|}{ Quartz } & \multicolumn{2}{|c|}{ Granite } \\
\hline Particle Size Distribution $^{+}$ & $\begin{array}{l}\text { Wt. \% } \\
\text { Passing }\end{array}$ & $\begin{array}{c}\text { Cum. Wt. \% } \\
\text { Retained }\end{array}$ & $\begin{array}{l}\text { Wt. \% } \\
\text { Passing }\end{array}$ & $\begin{array}{l}\text { Cum. Wt. \% } \\
\text { Retained }\end{array}$ \\
\hline $1 / 2$ inch $(12.5 \mathrm{~mm})$ & 100 & 0 & 99.4 & 0.6 \\
\hline $3 / 8$ inch sieve & 100 & 0 & 91.8 & 8.2 \\
\hline $1 / 4$ inch sieve & -- & -- & 40.0 & 60.0 \\
\hline$\# 4$ sieve $(4.75 \mathrm{~mm})$ & 99 & 1 & 14.2 & 85.8 \\
\hline$\# 5$ sieve $(4.00 \mathrm{~mm})$ & -- & -- & 6.3 & 93.7 \\
\hline$\# 8$ sieve $(2.36 \mathrm{~mm})$ & 96 & 4 & 0.6 & 99.4 \\
\hline$\# 16$ sieve $(1.18 \mathrm{~mm})$ & 81 & 19 & -- & -- \\
\hline$\# 30$ sieve $(600 \mu \mathrm{m})$ & 50 & 50 & -- & -- \\
\hline$\# 50$ sieve $(300 \mu \mathrm{m})$ & 17 & 83 & -- & -- \\
\hline$\# 100$ sieve $(150 \mu \mathrm{m})$ & 2 & 98 & -- & -- \\
\hline Fineness Modulus & -- & 2.6 & -- & -- \\
\hline
\end{tabular}

${ }^{+}$Percentage passing through each sieve as determined by ASTM C136. 

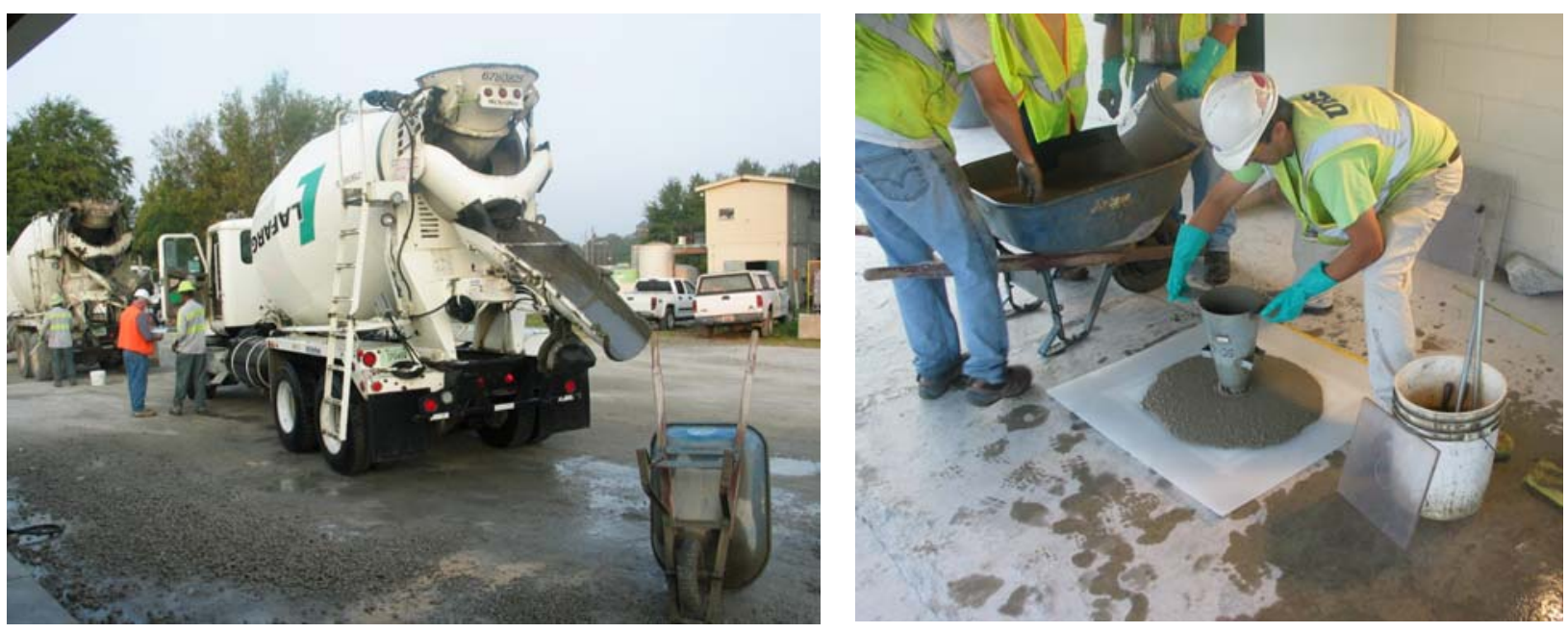

Figure 2-2. Admixture dose adjustment at the LaFarge batch plant based on ASTM C1611 test results.

\subsection{Test Methods}

Test methods are provided in Table 2-4. Descriptions of the test methods for evaluating fresh properties and cured grout properties are covered elsewhere [6].

Table 2-4. Test Methods Used to Determine Grout Properties.

\begin{tabular}{|c|c|}
\hline \multicolumn{1}{|c|}{ Properties } & ASTM Methods \\
\hline Fresh Properties & D6103 \\
\hline Flow (Initial and Static Flow) & C1611 \\
\hline Slump Flow & UPV and visual \\
\hline Set Time & C232 \\
\hline Bleed Water (24 hr.) & Visual \\
\hline Segregation & C138 \\
\hline Unit Weight & C231 \\
\hline Air Content & C1064 \\
\hline Grout Temperature & \\
\hline Thermal Property & Insulated 1 cubic yard monolith with \\
\hline Semi adiabatic temperature rise & embedded thermocouples \\
\hline Cured Properties & C39 \\
\hline Compressive Strength & D5084 Methods C or F \\
\hline Saturated Hydraulic Conductivity & \\
\hline
\end{tabular}

\subsection{Description of Semi Adiabatic Form}

SRR Construction fabricated a one cubic yard insulated plywood form with an insulated lid for the semi- adiabatic temperature rise measurement. The box was lined with a plastic sheet. Thermocouples 
were installed at the center of the box at the following elevations: $6,12,18,24$, and 30 inches from the bottom of the box and were supported by a PVC pipe. Additional thermocouples were placed along the center of one side and in a corner of the box 18 inches from the bottom and a few inches off the walls. The leads for the thermocouples were fed through the top of the box and were connected to a data logger. In addition, ambient temperature next to the form and $5 \mathrm{ft}$ from the form were also monitored for the duration of the test.

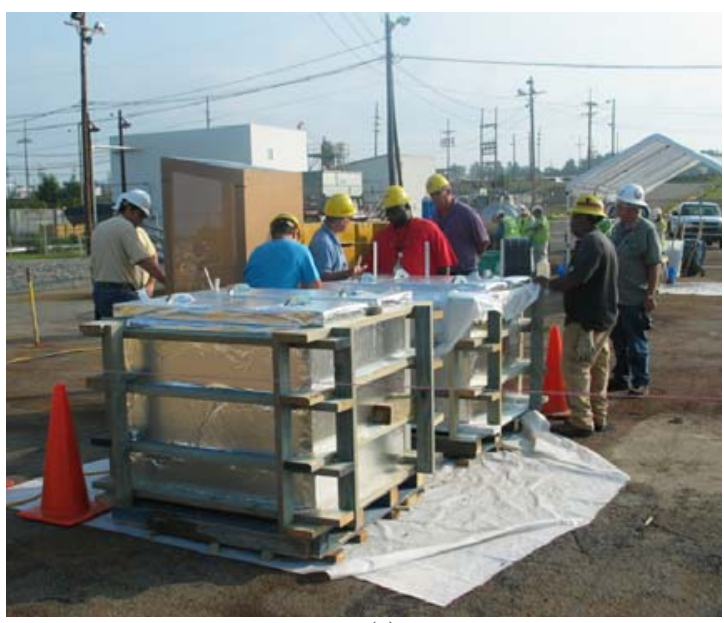

(a)

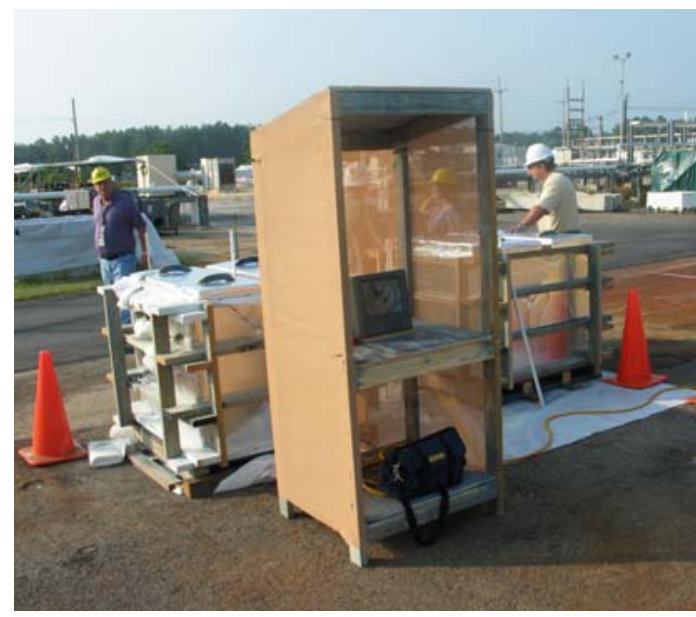

(b)

Figure 2-3. (a) Semi adiabatic test form and (b) Data logger set up.

\subsection{Semi Adiabatic Form Filling}

The semi-adiabatic form was filled by discharging directly from the truck into the form. The grout was more or less self-leveling and did not require finishing. See Figures 2-4(a) and (b). After the form was filled the insulated lid was placed on the box and was left in place for approximately one month as temperature readings were taken.

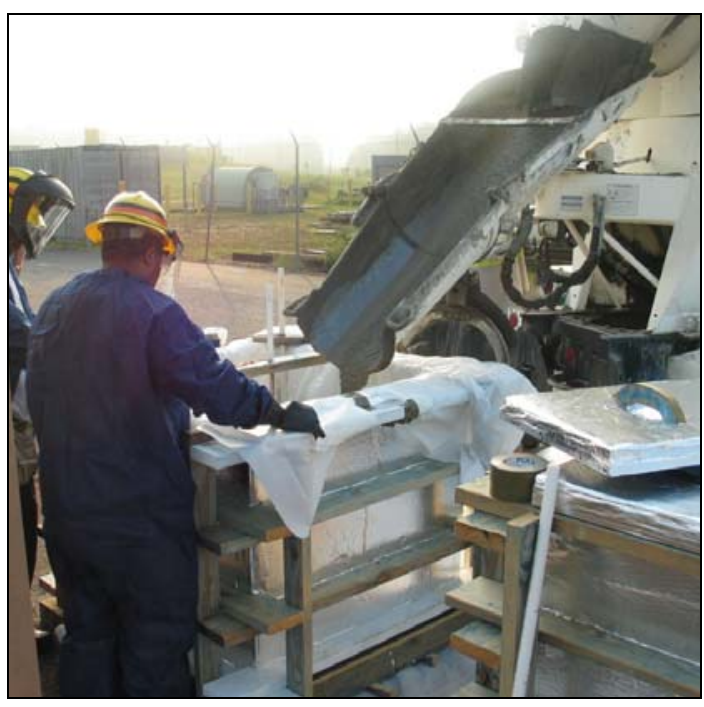

(a)

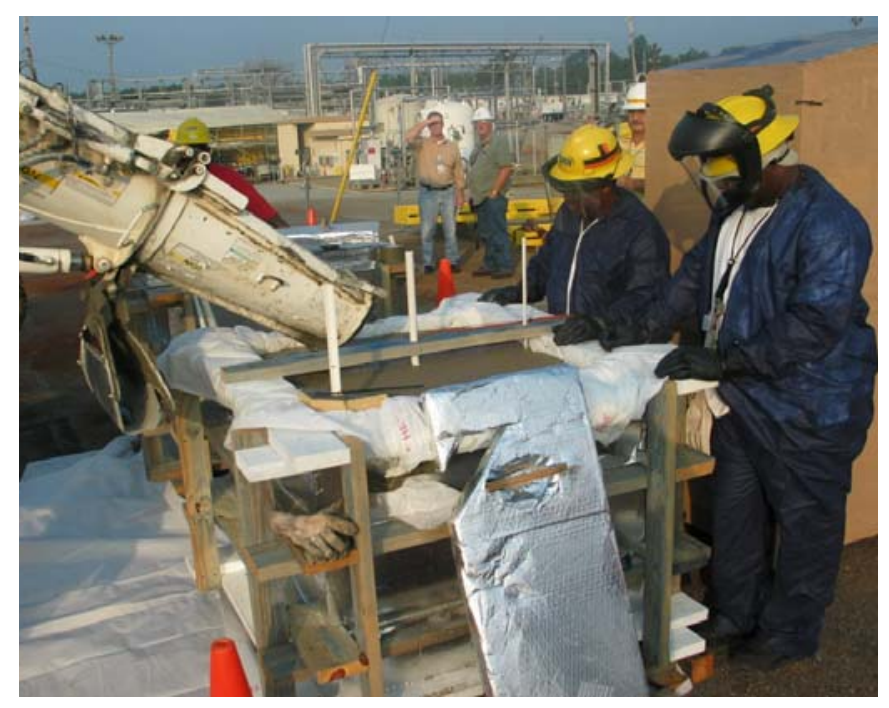

(b)

Figure 2-4. (a) Bulk tank fill grout placed into the semi adiabatic form and (b) Near full form. 


\subsection{RESULTS}

\subsection{Fresh Properties}

Several property measurements were identified in the bulk fill grout scale up test plan. Some of the fresh properties were measured at both the batch plant and at the point of delivery in F-Area. The slump flow per ASTM C1611 was 25.5 inches for material measured in F-Area which is 2.5 inch less than the slump flow measured at the batch plant. The values measured in F-Area were within the acceptable range and corresponded to values measured in the laboratory [6]. The initial spread, Figure 3-1 (a), and spread after static conditions for 15 and 30 minutes, Figure 3-1 (b) top left and top right, respectively illustrate the static working time

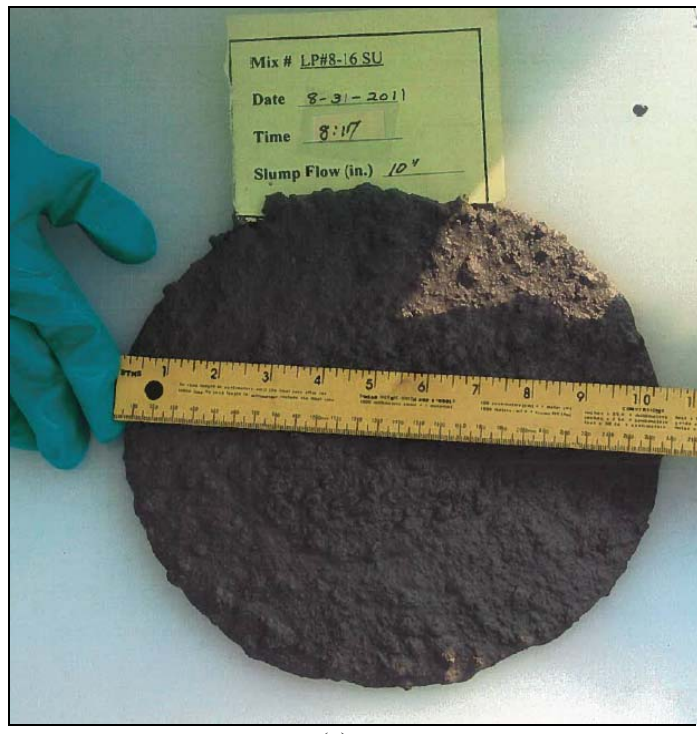

(a)

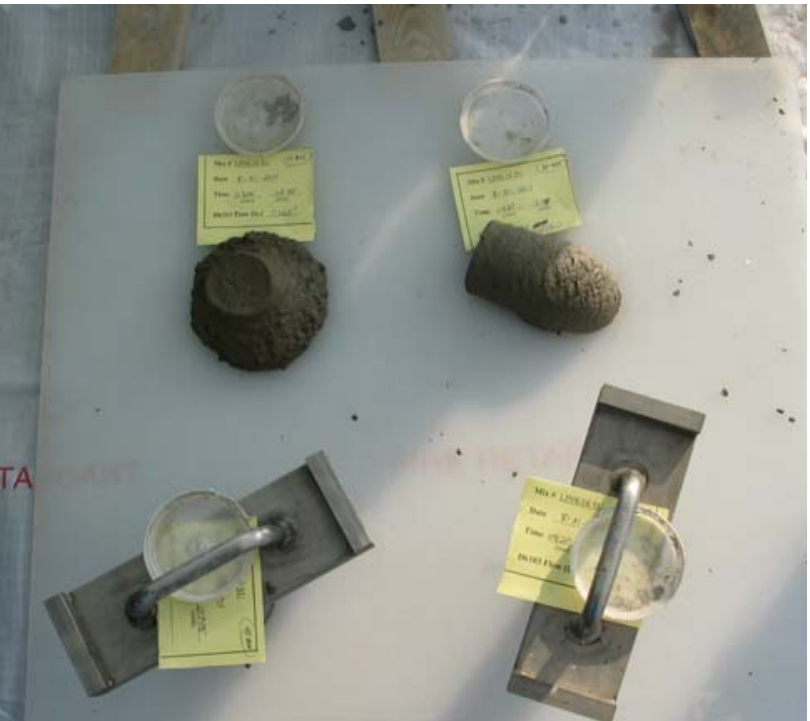

(b)

Figure 3-1. Spread under static conditions, (a) initial, (b) Top left 15 minutes, Top right 30 minutes.

This static gel time was significantly shorter than the time measured for a sample prepared in the laboratory, 9.5 inches at 30 minutes (laboratory sample) compared to 0 inches at 30 minutes (production sample). Different mixing conditions, a longer time between batching and testing, and ambient conditions may have contributed to part of this difference. However, it is more likely that ADVA 575 was not completely equivalent to the SIKA ViscoCrete 2100 and had slightly less gel retardation effect. Concrete admixtures are complex blends of several active chemicals and need to be adjusted to obtain desirable results. In this case a small amount of admixture to extend the static working time or adjustment of the ADVA 575 and EXP 958 (mixture of ADVA 575 and Diutan Gum) is warranted. Such adjustments may be required often during full-scale production.

Air content in the grout increased 0.3 volume percent after leaving the LaFarge batch plant. This reduced the measured unit weight from 136.6 to $135.1 \mathrm{lb} / \mathrm{cft}$. There was also a small increase in the ambient temperature and grout temperature $\left(<3^{\circ} \mathrm{F}\right)$.

The set time of the scale up mix, LP\#8-016SU, was 7.5 hours. Set time was determined using the Ultrasonic Pulse Velocity (UPV) method and the data is graphed in Figure 3-2. A small decrease in signal velocity was noticed just before the grout set. The cause for the slight velocity decrease is unknown and attributed to someone checking the sample during the test. 


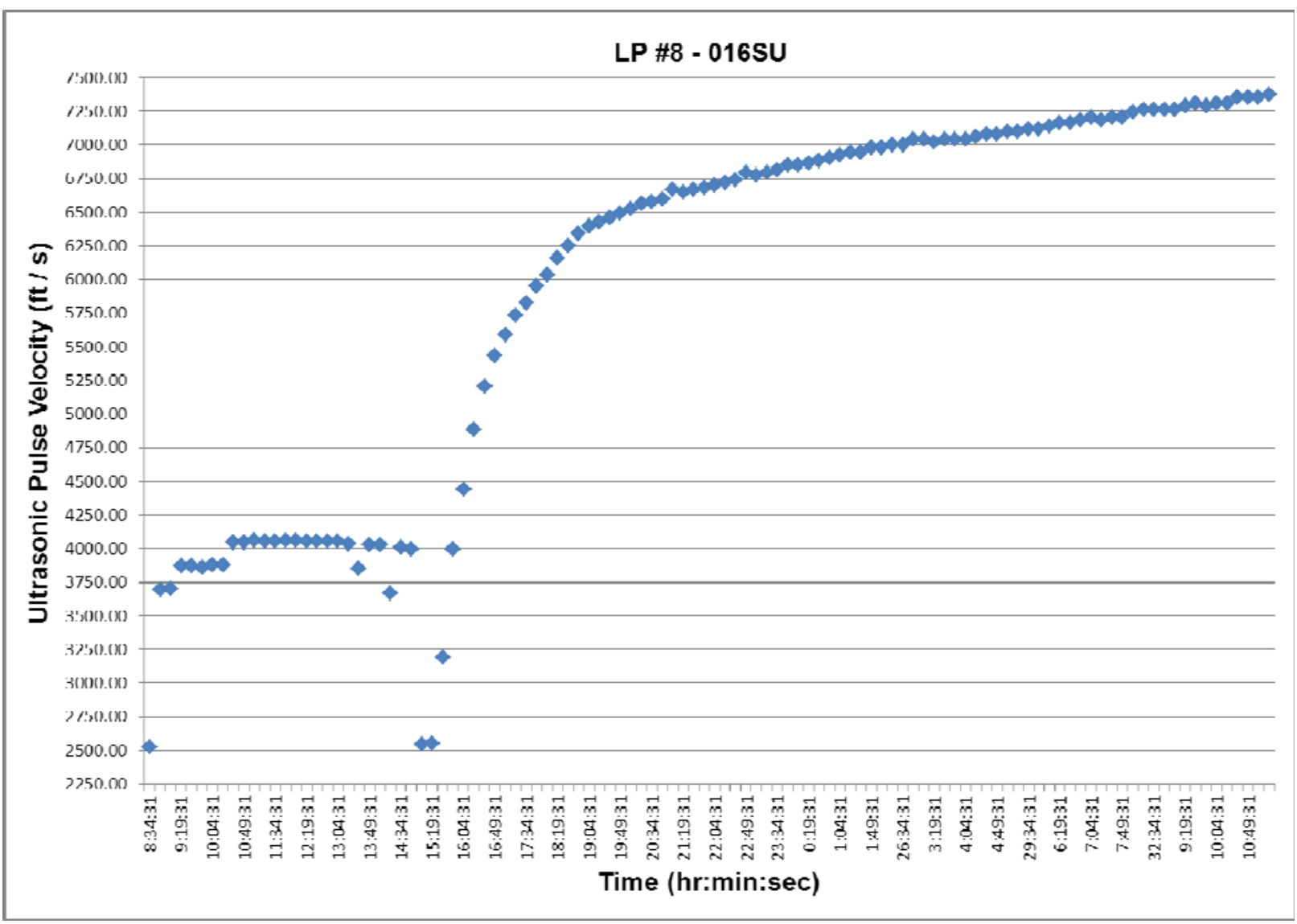

Figure 3-2. Velocity variation with time through a sample of the bulk fill grout collected from the scale up test batch.

The fresh properties are summarized in Table 3-1.

Table 3-1. Fresh Properties of the Bulk Fill Scale Up Mix.

\begin{tabular}{|c|c|c|c|}
\hline Properties & ASTM Methods & Batch Plant & FTF \\
\hline Slump Flow (inches) & C1611 & $\begin{array}{l}30 \times 26 \\
\text { Ave. } 28\end{array}$ & $\begin{array}{c}25.5 \times 25.5 \\
\text { Ave. } 25.5\end{array}$ \\
\hline Spread Initial (inches) & D6103 & Not measured & $10 \times 10$ \\
\hline $\begin{array}{l}\text { Spread (inches) after } \\
\text { static condition } \\
15,30,45 \text { min. }\end{array}$ & $\begin{array}{c}\text { SRNL Modified } \\
\text { D6103 }\end{array}$ & Not measured & $\begin{array}{c}\left.\mathrm{T}_{15}=7 \times 6.5 \text { (Ave. } 6.75\right) \\
\mathrm{T}_{30}=0 \times 0(\text { Ave. } 0) \\
\mathrm{T}_{45}=0 \times 0(\text { Ave. } 0)\end{array}$ \\
\hline Set Time (hr) & UPV and visual & Not measured & 7.5 \\
\hline Bleed Water (24 hr.) & C232 & Not measured & 0 \\
\hline Segregation & Visual & Not measured & 0 \\
\hline Unit Weight (lbs/cft) & C138 & 136.6 & 135.1 \\
\hline Air Content (vol. \%) & $\mathrm{C} 231$ & 0.8 & 1.1 \\
\hline Grout Temperature & $\mathrm{C} 1064$ & $75^{\circ} \mathrm{F}$ & $77^{\circ} \mathrm{F}$ \\
\hline Ambient Temperature & C1064 & $73.0^{\circ} \mathrm{F}$ & $76.6^{\circ} \mathrm{F}$ \\
\hline
\end{tabular}




\subsection{Thermal Properties}

The curing temperatures for the one cubic yard monolith are provided in Figure 3-3. Nine thermocouple locations are included in the graph. See Figure 3-4. Thermocouple data was collected over a period of 29 days. The peak temperature, $47^{\circ} \mathrm{C}$, occurred 82 hours after pouring the test form. The location was at the center of the box and 24 inches from the bottom. The temperature rise for the one cubic yard monolith was $23^{\circ} \mathrm{C}$. After 82 hours, the block temperature declined over the next 180 hours before leveling off for the next 120 hours. After 380 hours into the test, the outside temperatures fell during the day and the block temperature started declining again.

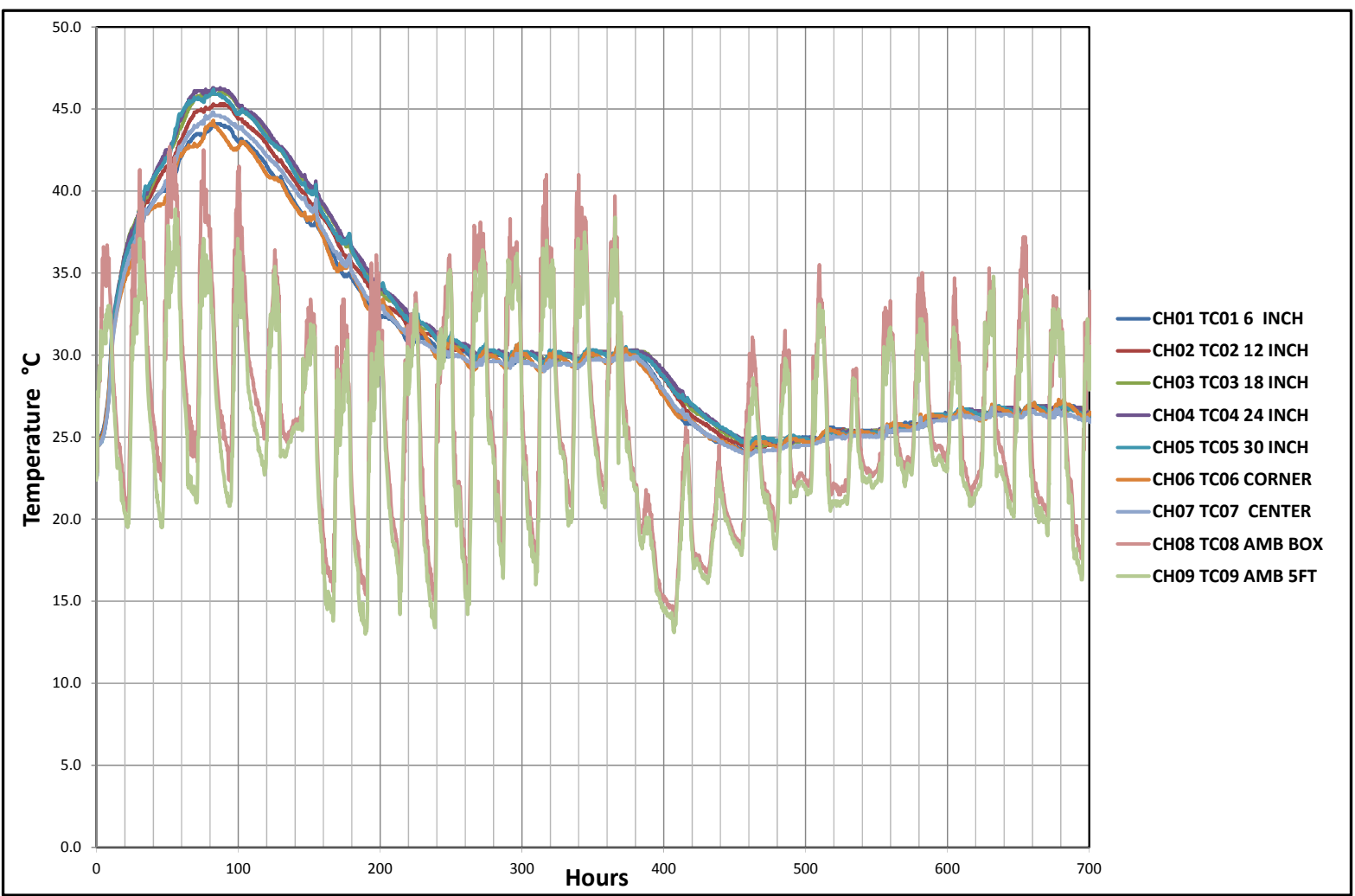

Figure 3-3. Tank fill grout - Semi-adiabatic temperature results for the one cubic yard monolith prepared on 8-31-2011. 
SRNL-STI-2011-00749

Revision 0

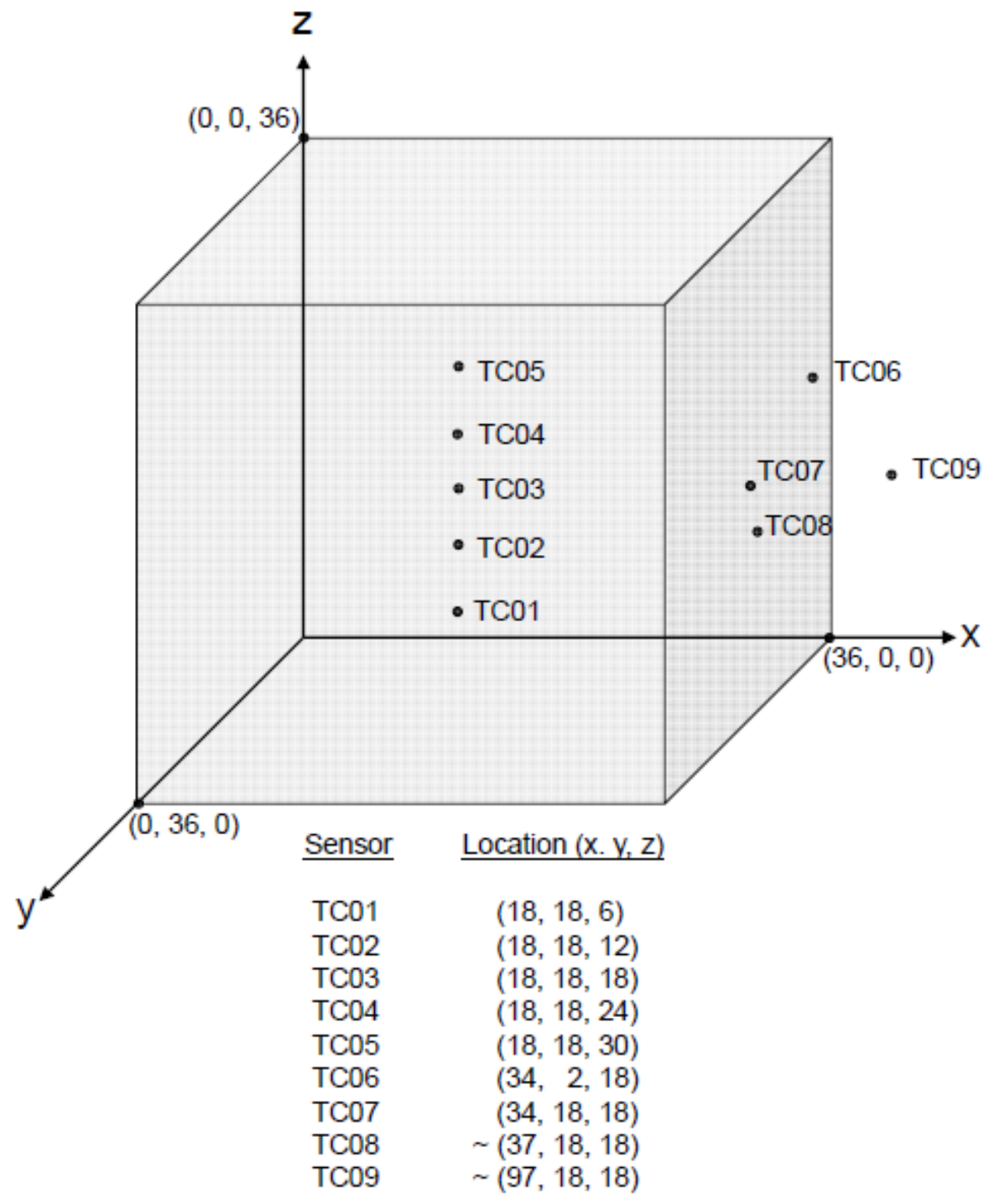

Figure 3-4. Map of thermocouple sensor locations for one cubic yard monolith.

\subsection{Cured Properties}

The cured properties results are provided in Table 3-2. Four inch by eight inch cylinders were cast for compressive strength measurements as a function of curing times (7, 28 and 90 days). Two by four inch cylinders and three by six inch cylinders were cast for hydraulic conductivity samples. Samples were prepared according to ASTM C192 and cured in a constant temperature $\left(73^{\circ} \mathrm{F} \pm 2^{\circ} \mathrm{F}\right)$ curing room at $100 \%$ relative humidity until ready for testing. Two cylinders were broken during each compressive strength time interval. These strengths and averages are included in Table 3-2.

Saturated hydraulic conductivity, density, and porosity were identified as optional parameters in the scale up test plan. These properties were not measured. Segregation was evaluated by visual examination. The grout did not segregate. 
SRNL-STI-2011-00749

Revision 0

Table 3-2. Cured Properties of the Bulk Fill Scale Up Mix.

\begin{tabular}{|l|c|c|}
\hline Properties & ASTM Methods & Result \\
\hline Compressive Strength $(\mathrm{psi})$ & C39 & \\
\hline 7 days $(2)$ & & $350,380(365$ ave. $)$ \\
\hline 28 days (2) & & $2870,2770(2820$ ave. $)$ \\
\hline 90 days (2) & & $5020,4790(4905$ ave. $)$ \\
\hline
\end{tabular}

\subsection{CONCLUSIONS AND RECOMMENDATIONS}

The scale up testing confirmed that offsite batching at a commercial plant and delivering the bulk fill material recommended by SRNL for filling Tanks 18-F and 19-F is feasible. Material batching and delivery to the F area Tank Farm was achieved in less than one hour.

The slump flow measured per ASTM C1611 in F-Area was within the acceptable range (24 to 28 inch) in the procurement specification and corresponded to values measured in the laboratory [6]. The static gel time was significantly shorter than the time measured for samples prepared in the laboratory, 9.5 inches at 30 minutes in the laboratory compared to 0 inches at the 30 minutes at the point of delivery. This difference is attributed to a longer time between batching and testing and the concrete admixture differences (Sika ViscoCrete 2100 during laboratory samples versus ADVA 575 and EXP 958 during scale up testing).

There was no significant change in the air content, unit weight and temperature of the grout for values measured at the concrete batch plant versus values measured at F-Tank Farm.

The set time of the scale up mix was 7.5 hours. This is less than the 24 hours requirement to sustain next day operations and meets the production requirement for filling the waste tanks.

The average compressive strength measured from samples cured for 28 days was 2800 psi. This meets the Performance Assessment (PA) and Engineering requirement ( $>2000$ psi at 28 day).

The temperature rise under semi-adiabatic conditions was $23^{\circ} \mathrm{C}$ for the insulated 1 cubic yard monolith poured, and occurred after 82 hours. Beyond 82 hours, the block temperature declined. This meets the objective for developing a grout that can be mass placed.

Saturated hydraulic conductivity, density and porosity were identified as optional parameters in the scale up test plan and not measured. 


\subsection{REFERENCES}

1. SRR Closure and Waste Disposal Authority, 2011. "Industrial Wastewater Closure Module for the Liquid Waste Tanks 18 and 19 F-Area Tank Farm, Savannah River Site," SRR-CWDA-201000003, Revision 0, August 2011, Industrial Waste Water Construction Permit No. 17,424-IW, Savannah River Remediation LLC, Savannah River Site, Aiken, SC, 29808.

2. Hyche, J. P., 2011. “Tier 1Bulk Grout Fill Test Plan,” M-TPL-F-00012, August 30, 2011, Savannah River Remediations, LLC, Savannah River Site, Aiken, SC, 29808.

3. Chandler, V. A., 2011. "Technical Task Request: Develop Tank Closure Technology Grout Formulations for Tanks(s) 18 \& 19," HLE-TTR-2011-008, March 10, 2011, Savannah River Remediation, LLC, Savannah River Site, Aiken, SC, 29808.

4. Stefanko, D. B., Guerrero, H. N., Reigel, M. M., and C. A. Langton, 2011. "Task Technical and Quality Assurance Plan for Developing and Testing Grout Formulations for Filling Tanks 18-F and 19-F and Abandoned Equipment," SRNL-RP-2011-00587, Revision 0, March 22, 2011, Savannah River National Laboratory, Savannah River Site, Aiken, SC, 29808.

5. Stefanko, D. B. and C. A. Langton, 2011. "Tanks 18-F and 19-F Grout Fill Engineering and Performance Requirements," SRNL-STI-2011-00977, Revision 0, August 2011, Savannah River National Laboratory, Savannah River Site, Aiken, SC, 29808.

6. Stefanko, D. B. and C. A. Langton, 2011. "Tank 18-F and 19-F Structural Flowable Grout Fill Material Evaluation and Recommendations," SRNL-STI-2011-00551, Revision 0, September 2011, Savannah River National Laboratory, Savannah River Site, Aiken, SC, 29808. 


\section{Distribution:}

A. B. Barnes, 999-W

H. H. Burns, 773-43A - Rm.227

B. T. Butcher, 773-43A - Rm.212

P. E. Carroll, 704-71F

V. A. Chander, 704-70F

L. B. Collard, 773-43A - Rm.207

D. A. Crowley, 773-43A - Rm.216

S. D. Fink, 773-A

B. J. Giddings, 786-5A

M. E. Harrel, 241-108F

J. E. Herbert, 241-108F

C. C. Herman, 999-W

J. P. Hyche, 704-70F

R. C. Jolly, 241-109F

C. A. Langton, 773-43A

S. L. Marra, 773-A

W. L. Mhyre, $717-5 \mathrm{~N}$

B. A. Martin, 705-1C

A. M. Murray, 773-A

M. E. Pallon, 717-11F

F. M. Pennebaker, 773-42A

W. Pope Jr., 717-5N

K. H. Rosenberger, 705-1C

J. W. Rush, 241-108F

J. H. Scogin, 773-A

M. G. Serrato, 773-42A

A. J. Tisler, 704-26F

R. O. Voegtlen, 704-71F

J. T. Waymer, $717-5 \mathrm{~N}$

W. R. Wilmarth, 773-A

D. C. Wood, 704-26F

(1 file copy \& 1 electronic copy), 773-43A - Rm.213 